\title{
PERAN HUBUNGAN INTERAKTIF TERHADAP PERTUMBUHAN INDUSTRI E-COMMERCE DAN EVOLUSI INDUSTRI JEJARING SOCIAL MEDIA
}

\author{
Hilarius Bambang Winarko \\ Sampoerna School of Business
}

\begin{abstract}
Dewasa ini penggunaan social media menunjukkan tren yang semakin meningkat dalam skala global. Dengan peningkatan yang pesat tersebut, penggunaan situs-situs internet dalam jejaring social media seperti misalnya Blog, Facebook, Youtube,Twitter, dsb. memiliki dampak yang berarti terhadap tahap pengembangan suatu bisnis pada umumnya dan membentuk pola baru perdagangan elektronik dunia maya (E-commerce) di masa yang akan datang. Tulisan ini merupakan sumbangan tinjauan pemikiran dari sudut pandang bisnis yang mungkin dapat dimanfaatkan untuk keperluan riset manajemen lebih lanjut terhadap aspek hubungan interaktif dalam penggunaan jejaring social media, berkaitan dengan peranannya sebagai salah satu faktor pendorong pertumbuhan industri E-commerce dalam skala global, serta peranannya dalam evolusi industri jejaring social media.
\end{abstract}

Keywords:

Hubungan interaktif, industri e-commerce, industri jejaring social media 


\section{PENDAHULUAN}

"No man is an island." Demikian dikatakan oleh sastrawan Inggris John Donne. Manusia adalah makhluk sosial dan memerlukan keterhubungan atau interaksi satu sama lain dengan manusia lainnya agar mampu bertahan hidup. Interaksi sosial kemudian dikenal dalam berbagai macam hubungan dalam masyarakat, baik dalam bentuk hubungan individu, ikatan pernikahan, keluarga, teman sekolah, institusi pemerintah, bahkan perusahaan.

Dalam bisnis, manusia juga menempati perhatian yang penting dalam menentukan sukses tidaknya suatu transaksi bisnis. Besarnya tingkat supply dan demand suatu produk akan ditentukan apabila seseorang merasa membutuhkan atau menginginkan kehadiran barang ataupun jasa tertentu. Secara umum, hubungan interaktif yang terjadi dalam dunia bisnis biasanya melibatkan interaksi di antara ketiga belah pihak yang berkepentingan dan berkaitan erat satu sama lainnya. Yang pertama adalah perusahaan, yaitu pihak yang menyediakan barang dan jasa kepada pelanggan. Yang kedua adalah karyawan, yang merupakan salah satu faktor produksi penghasil barang dan jasa, sekaligus menjadi jembatan antara perusahaan dan pelanggan. Dan yang terakhir adalah pelanggan, yaitu pihak yang membeli atau menggunakan barang dan jasa yang dihasilkan oleh perusahaan dan karyawannya. Karena ketiga pihak tersebut saling terkait erat, maka mereka sangat menentukan sejauh mana dinamika suatu bisnis mampu bertumbuh dengan sehat atau tidak. Perusahaan tidak akan dapat berjalan dengan baik apabila tidak memiliki SDM yang kompeten yang selain mengerti bagaimana mengelola faktor produksi, namun juga mengerti apa yang diinginkan dan dibutuhkan oleh tiap-tiap profil pelanggan.

Setiap perusahaan memiliki keinginan untuk berkembang menjadi institusi yang memiliki daya saing tinggi dibanding kompetitornya, sehingga dapat sustainable atau bertahan dalam jangka waktu yang relatif panjang melalui penyediaan barang dan jasa yang mampu memberikan kepuasan pada pelanggannya.

Guna memenuhi kepuasan pelanggan, berbagai macam teknik dalam ilmu manajemen diterapkan, namun dalam prakteknya sangat bergantung kepada manusia sebagai subyek utamanya. Tidak sedikit perusahaan yang ingin dan telah mengadopsi layanan otomatisasi dalam rangka mengefisiensikan kinerja operasional perusahaannya. Dengan bantuan teknologi maju terkini, perusahaan modern dimampukan menghasilkan suatu produk dalam waktu yang sesingkat mungkin, dengan ongkos seminimal dan menghasilkan barang dan jasa dengan kualitas yang sekonsisten mungkin.

Namun demikian para pebisnis mencoba mencari solusi tepat terhadap permasalahan penting lainnya, yaitu: apakah dengan demikian serta merta pelanggan menjadi terpuaskan dan loyal terhadap produk tersebut dalam jangka waktu panjang, apakah produk yang dihasilkan tersebut dapat menjangkau pasar seluas-luasnya secara efisien dan efektif, dan sejauh mana konsumen dapat secara nyaman dan percaya untuk mendapatkan dan menggunakan produk tersebut. Dalam hal ini produsen harus memperhatikan aspek manusia si pelanggan dan meninggalkan konsep pemasaran yang berorientasi pada produk (product-oriented marketing).

Dalam konsep pemasaran yang
berorientasi pelanggan marketing) telah banyak diulas berbagai macam strategi perusahaan yang bersumber pada program Bauran Pemasaran (Marketing Mix) tradisional dengan komponen dasar 4P (Product, Price, Place, Promotion). Tujuan utama upaya teknik pemasaran ini adalah sama, yaitu bagaimana agar perusahaan penyedia barang dan jasa dapat berinteraksi dengan konsumen atau pelanggan, sehingga perusahaan dapat berproduksi ataupun memberikan layanan dengan skala ekonomis sesuai dengan apa yang benar-benar menjadi kebutuhan dan keinginan konsumen, namun tetap memberikan keuntungan bagi perusahaan dari setiap transaksi bisnisnya. Dari keempat elemen 4P tersebut, Promotion mendapat perhatian khusus, mengingat peranannya sebagai elemen Bauran Pemasaran yang kerap digunakan pebisnis dalam upaya menarik perhatian pelanggan dan mendongkrak volume penjualan, sehingga perusahaan dapat memenangkan sebuah persaingan bisnis. 
Dalam konsep Relationship Management (RM), yaitu suatu cabang dalam ilmu pemasaran yang berfokus pada bagaimana mempertahankan dan memuaskan pelanggan daripada semata-mata hanya berfokus pada penjualan produk, diketahui bahwa konsep RM ternyata dapat diaplikasikan di berbagai macam jenis industri.

Sebuah temuan penting dalam sebuah riset Relationship Management menyatakan bahwa dengan teknologi maju saat ini, secara spesifik teknologi internet, Web-based Promotion dapat dijadikan sarana efektif yang saat ini dan ke depan mendominasi kegiatan pengembangan bisnis (business development) dalam memberikan penawaran terhadap suatu pasar (market offerings). Tidak hanya itu saja, Web-based Promotion ternyata mampu meningkatkan daya saing perusahaan. Riset ini menggunakan suatu model penelitian yang melibatkan baik website yang dikelola sendiri oleh perusahaan obyek riset, maupun situs-situs terkait dengan jejaring social media, seperti misalnya Blog, Facebook, Youtube, Twitter. Web-based Promotion yang dikelola oleh suatu perusahaan secara mandiri dan berkolaborasi dengan jejaring social media ternyata mampu mendukung bertumbuhnya suatu perusahaan. Bahkan tidak mustahil para pemasar ke depan dapat memanfaatkan Web-based Promotion dengan strategi bertumbuh dalam matriks Product-Market, seperti misalnya market penetration, market develepment, product development, dan diversification.
Menanggapi fenomena tersebut di atas muncul berbagai pertanyaan kritis, seperti: sejauh mana efektivitas suatu perusahaan dalam memanfaatkan jejaring social media untuk mendukung strategi bertumbuhnya. Selanjutnya, sejauh mana penyedia layanan social media dapat berevolusi menjadi perusahaan $E$ commerce dalam skala global seiring dengan perkembangan teknologi web terbaru dan mampu menjadi media penghubung interaktif yang efektif antar perusahaan, karyawan dan pelanggan (customer-oriented E-commerce) sehingga ketiga pihak yang berkepentingan dapat menikmati manfaat secara bersamaan (mutual benefits)? Atau akankah perusahaanperusahaan E-commerce juga menemukan pola bisnis baru dengan cara mengembangkan platform teknologi web-nya?

\section{ERA E-COMMERCE}

Era persaingan di bisnis perdagangan elektronik (E-commerce) mulai semarak sejak periode pertengahan tahun 1990-an sampai tahun 2000-an seiring dengan munculnya perusahaan-perusahaan baru di bidang $E$ commerce yang dipercaya saat itu akan memiliki prospek yang cukup menjanjikan sebab menjadi suatu kekuatan ekonomi dunia baru dan merupakan sarana untuk meraih daya saing perusahaan (competitive advantage) seperti terlihat pada Tabel 1.

Tabel 1.

Competitive Advantage of E-commerce

\begin{tabular}{|c|c|c|c|c|c|}
\hline \multicolumn{6}{|c|}{ Examples of reduction of the costs of commercial transactions } \\
\hline & $\begin{array}{l}\text { Booking an } \\
\text { airplane ticket }\end{array}$ & $\begin{array}{l}\text { Banking } \\
\text { transaction }{ }^{\mathrm{a}}\end{array}$ & Bill paying ${ }^{a}$ & $\begin{array}{l}\text { Software } \\
\text { distribution }^{\mathrm{a}}\end{array}$ & Stockbroking ${ }^{\mathrm{b}}$ \\
\hline Traditional system & $\$ 8.00$ & $\$ 1.08$ & US $\$ 2.22-3.32$ & US\$15.00 & US\$150to 60 \\
\hline Via Internet & $\$ 1.00$ & $\$ 0.13$ & US $\$ 0.65-1.10$ & US\$0.20-0.50 & US\$10 \\
\hline Cost reduction & $87 \%$ & $89 \%$ & 71 to $67 \%$ & $97-99 \%$ & 93 to $83 \%$ \\
\hline \multicolumn{6}{|c|}{ Examples of competitive advantage for mamufacturing firms } \\
\hline & Development costs ${ }^{c}$ & $\begin{array}{l}\text { Number of } \\
\text { engineering } \\
\text { changes }^{c}\end{array}$ & $\begin{array}{l}\text { Rejects and } \\
\text { adjustments }^{c}\end{array}$ & $\begin{array}{l}\text { Document } \\
\text { distribution }^{\mathrm{c}}\end{array}$ & $\begin{array}{l}\text { Reduction of new } \\
\text { product design } \\
\text { time }{ }^{c}\end{array}$ \\
\hline Reduction relative to traditional system & $25-35 \%$ & $50-90 \%$ & $75-95 \%$ & $80 \%$ & $40-60 \%$ \\
\hline
\end{tabular}


Para pebisnis yang membangun bisnisnya di bidang E-commerce memiliki asumsi dasar bahwa dengan menampilkan suatu produk di sebuah situs internet, maka siapapun di seluruh dunia, asalkan terkoneksi dengan jaringan internet, dapat menjadi target market yang potensial.

Bisa dibayangkan bahwa sebuah situs internet secara ideal dapat berperan sebagai etalase toko maya yang sangat besar yang mampu menampilkan beragam item produk yang hendak dijual, berikut dengan segala informasi dan berbagai penawaran yang menarik dari konsumen atau kelompok konsumen yang lebih besar. Apabila tertarik, maka calon pelanggan yang terhubung dengan situs tersebut dapat dengan nyaman dan cepat melakukan transaksi bisnis, baik melalui suatu media sistem pelelangan elektronik (E-auction) ataupun transaksi jual-beli secara langsung dengan berbagai opsi moda pembayaran: transfer bank ataupun fasilitas kartu kredit. Apabila data pelanggan, seperti: jumlah dan item produk yang dibeli, alamat pengiriman, dan cara pembayaran telah berhasil diverifikasi oleh pihak penjual, maka pihak penjual kemudian dapat mengirimkan barangnya kepada pihak pembeli. Dengan demikian perdagangan elektronik di dunia maya ini dinilai cukup efisien dan efektif penggunaannya.

Mekanisme dalam era perdagangan elektronik ini awalnya dirasakan cukup praktis bagi konsumen, disamping juga menawarkan berbagai manfaat bagi produsen, terutama dalam hal efektivitas penunjang kegiatan promosi pemasaran produknya. Namun ternyata banyak perusahaan-perusahaan E-commerce tidak mampu berkembang lebih jauh atau secepat yang diharapkan oleh para pakar sebelumnya. Mengapa demikian?

Dahulu infrastruktur perdagangan elektronik di dunia maya dinilai masih belum sempurna dan memiliki beberapa keterbatasan. Alasan klasik yang sering dikemukakan oleh para ahli terutama adalah alasan teknis, belum ditemukannya killer application yang mendukung, atau platform teknologi web yang masih bersifat statik atau belum interaktif, ketersediaan infrastruktur teknologi informasi dan komunikasi di suatu negara yang memerlukan investasi yang tidak sedikit, serta faktor keamanan transaksi dan kerahasiaan pelanggan melalui transaksi berbasis web.

Saat ini faktor teknologi tersebut sudah bukan menjadi hambatan utama, sebagaimana dengan penemuan platform teknologi web 2.0, di mana pihak penjual dan pembeli dapat melakukan hubungan interaktif seperti layaknya dalam suatu transaksi bisnis konvensional. Atau bahkan dengan pengembangan web 3.0 di kemudian hari, di mana transaksi bisnis online dapat dilakukan secara lebih personal melalui telepon genggam, smartphone, ataupun perangkat multimedia elektronik lainnya, apakah serta merta bisnis perdagangan elektronik (E-commerce) di dunia maya sudah menemukan solusi komprehensif terhadap akar permasalahan utamanya?

\section{KARAKTERISTIK BISNIS E- COMMERCE}

Salah satu model bisnis yang ditawarkan dalam bisnis perdagangan elektronik (E-commerce) adalah sebagai promoter atau intermediary dari satu atau beberapa kelompok perusahaan penyedia produk dalam industri sejenis. Dalam hal ini pihak promoter menyediakan fasilitas website sebagai media promosi produk kliennya dan penyedia jasa E-commerce dapat memperoleh fee atas jasa dari setiap transaksi bisnis yang dihasilkannya. Amazon.com adalah salah satu contoh klasik perusahaan global E-commerce yang terbesar dan tersukses saat ini yang pada tahun 2010 
lalu berhasil membukukan penjualan sebesar USD 34 Miliar dengan total karyawan sebanyak 33,700 orang. Didirikan oleh Jeff Bezos pada tahun 1995, Amazon.com yang berkantor pusat di Seattle, Amerika Serikat pada awalnya merupakan bisnis online yang hanya menjual item buku. Dari produk buku $\begin{array}{lrr}\text { online, Amazon.com } & \text { kemudian } \\ \text { menumbuhkan } & \text { bisnisnya } & \text { dengan }\end{array}$ memperluas produknya dengan menjual unduhan DVD, CD, MP3, perangkat lunak komputer, peralatan elektronik, pakaian, furnitur, mainan anak-anak makanan sampai dengan item makanan (Gambar 1.).

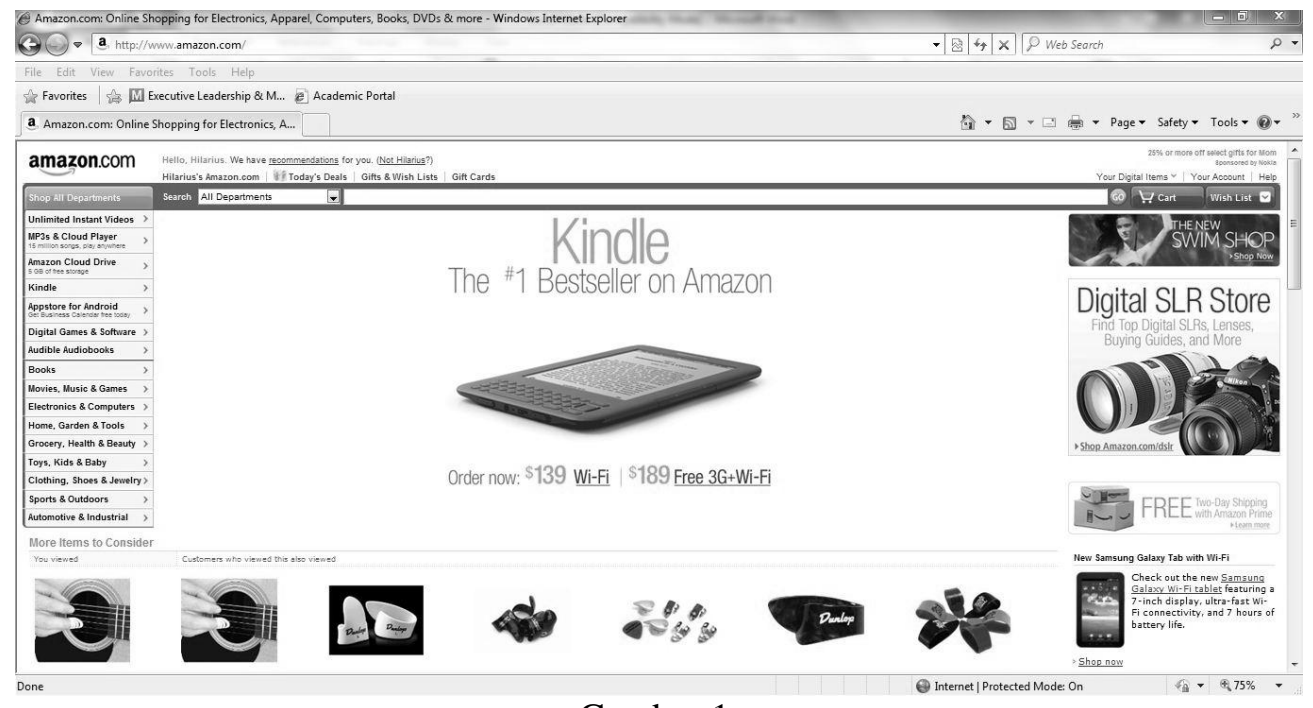

Gambar 1.

Contoh Tampilan Situs Amazon.com

Menjual buku secara online tentunya tidak sesulit menjual furnitur, pakaian dan bahkan makanan secara on-line. Dalam hal penjualan buku secara online, Amazon.com telah mampu membangun kepercayaan pelanggan, walaupun model bisnis $E$ commerce secara umum memerlukan jangka waktu yang lama agar dapat benar-benar diterima oleh pasar. Beberapa faktor pendukungnya adalah karena risikonya yang relatif lebih kecil, sifat produk yang ditawarkan tidak cepat kadaluwarsa, kemasan dan pengirimannya cukup sederhana dan murah. Dalam hal transaksi jual-beli buku, faktor 'hubungan interaktif' atau tingkat keterlibatan antara pembeli dan penjual relatif tidak tinggi (low level of involvement). Dengan demikian faktor kepuasan pelanggan hanya banyak dipengaruhi oleh kualitas konten buku yang dibeli apakah sudah sesuai dengan harapan atau tidak, bukan pada kualitas layanannya.

Bagaimana strategi Amazon.com dalam menerapkan strategi bertumbuh bisnis E-commerce-nya? Dengan memperluas lini produk, tidak berarti Amazon.com harus memulai dari awal memetakan proses bisnis dan membangun infrastruktur unit bisnisnya dari nol. Pada tahun 2009, Jeff Bezos mengakuisisi perusahaan lain yaitu Zappos.com, sebuah perusahaan berbasis $E$ commerce yang berkantor pusat di Nevada, Amerika Serikat yang menjual barangbarang seperti misalnya sepatu, pakaian, kacamata dan asesoris lainnya secara online (Gambar 2.). 


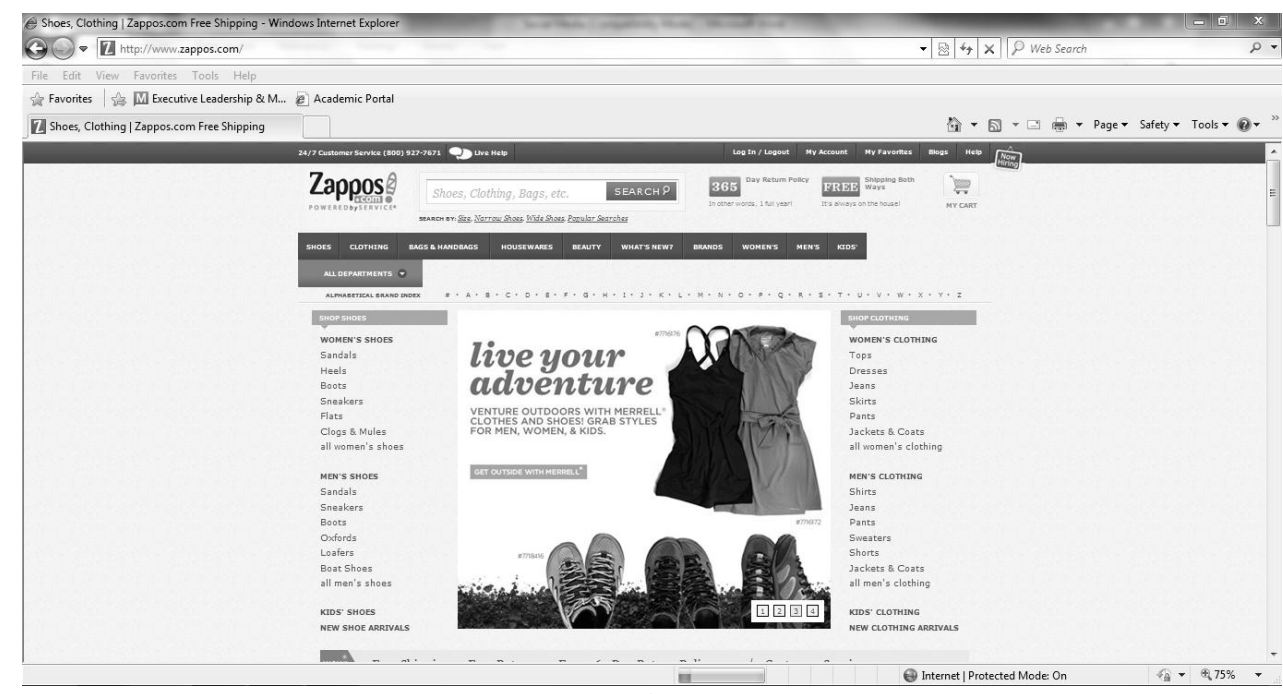

Gambar 2.

Contoh Tampilan Situs Zappos.com

Dengan jumlah karyawan 1,550 orang saat ini Zappos.com memiliki lebih dari 10 juta pelanggan per tahunnya dengan nilai omzet USD 1 Miliar dan lebih dari $75 \%$ penjualannya berasal dari pelanggan yang loyal (repeat order). Perusahaan bisnis online ini dinilai cukup sukses mengingat dengan krisis ekonomi di Amerika Serikat, mereka mampu menumbuhkan penjualannya lebih dari $20 \%$ pada tahun 2010 yang lalu Ditinjau dari karakteristik bisnis-nya, Zappos.com dan Amazon.com memiliki kesamaan dan perbedaan walaupun keduanya masuk dalam kategori bisnis $E$ commerce yang sama. Lalu apa yang menjadi kunci sukses dari perusahaan bisnis online atau perusahaan dotcom tersebut?

Pertanyaan yang mungkin muncul dalam benak konsumen ketika hendak membeli barang-barang seperti sepatu dan pakaian secara online adalah bagaimana kecocokan ukuran dan keserasian secara fisik ketika produk tersebut dipergunakan oleh konsumen. Lain halnya apabila seseorang ingin membeli produk yang sama di toko konvensional, konsumen mendapat kesempatan mencoba produk secara langsung. Pertanyaan yang sama tidak muncul dalam benak konsumen buku online, karena umumnya konsumen menitikberatkan pada kualitas konten buku yang dibelinya daripada kualitas fisik yang diharapkannya.

Untuk mengatasi hambatan tersebut, CEO Zappos.com, Tony Hsieh menyatakan bahwa Zappos memiliki visi yang unik, yaitu menjadi perusahaan online yang berorintasi pada customer service dan customer experience. Keunikan strategi Zappos.com dapat dilihat dari komitmen mereka dalam memberikan suatu terobosan layanan yang secara psikologis seolah-olah pelanggan akan merespon dengan kata "WOW". Dalam hal ini Zappos.com memberikan komitmen layanan yang lebih dibanding kompetitornya, seperti misalnya: bebas ongkos kirim, bebas ongkos pengembalian produk, garansi produk 365 hari, 24/7 customer service, dan layanan hotline. Walaupun dengan cakupan area pelayanan yang masih terbatas, dengan terobosan penawaran layanan yang unik tersebut Zappos.com mencoba mengatasi resistensi konsumen untuk tidak ragu mencoba layanan E-commerce-nya, sehingga hambatan fisik seperti kesulitan dalam 
mencoba produk sepatu dan pakaian menjadi tidak relevan lagi.

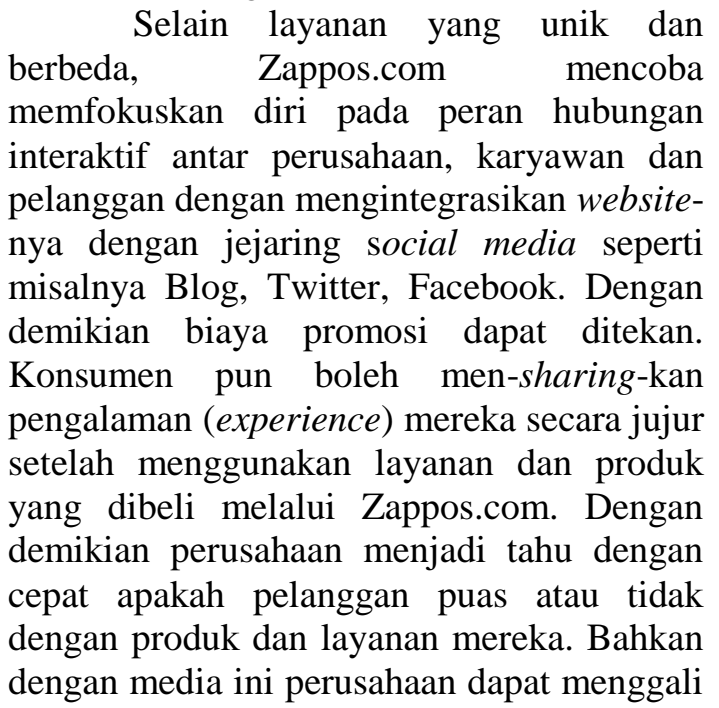

lebih jauh dari pengalaman pelanggan kemungkinan adanya informasi produk dan layanan kompetitor. Percakapan (conversation) atau hubungan interaktif tidak hanya terjadi di antara komunitas pelanggan, tetapi juga antar pelanggan dan karyawan melalui online customer service, bahkan interaksi antar karyawan dan bisa dilihat secara transparan oleh pelanggan melalui media Twitter (Gambar 3.). Hal ini dilakukan oleh Zappos.com, karena mereka percaya bahwa hanya dengan menciptakan budaya kerja dalam bentuk komunikasi yang menyenangkan di antara sesama karyawan, perusahaan dapat meningkatkan kepuasan pelanggan sesuai dengan komitmen yang dibangun oleh CEO Tony Hsieh.

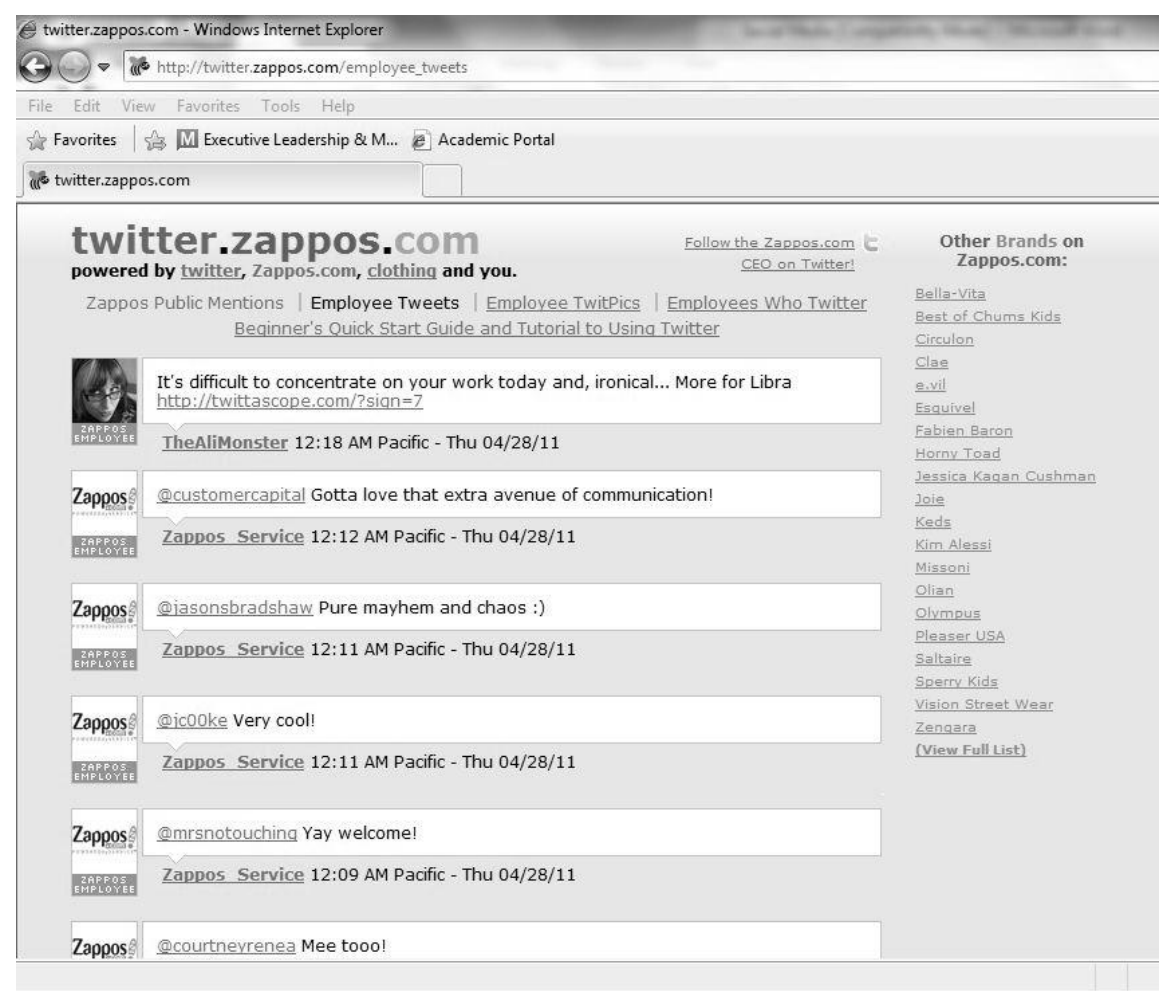

Gambar 3.

Komunikasi Antar Karyawan Zappos.com Melalui Twitter 
Dari pengalaman Amazon.com dan Zappos.com di atas, dapat dilihat bahwa keberhasilan perusahaan global papan atas di bidang E-commerce tidak terlepas dari aspek hubungan interaktif baik antar manusia-manusia dan manusia-lembaga. Yaitu sejauh mana dinamika interaksi bisnis antar perusahaan, karyawan dan pelanggan di dunia nyata dapat terwakili oleh perusahaan E-commerce di dunia maya dengan bantuan teknologi dan jejaring social media. Pertanyaan selanjutnya adalah seberapa jauh nilai tambah yang dapat diberikan oleh bisnis online E-commerce, mengingat perusahaan-perusahaan skala global dan multinasional juga mampu memanfaatkan tekonologi dengan mengelola Web-based Promotion secara mandiri dan berkolaborasi dengan jejaring social media sebagai pelengkap bisnis tradisionalnya dan menumbuhkan bisnisnya di dunia maya.

Kompetensi bisnis perdagangan elektronik (E-commerce) tidak jauh berbeda dengan kompetensi bisnis sebagaimana lazimnya dunia perdagangan di dunia nyata. Dalam sebuah perusahaan distribusi misalnya, nilai tambah konvensional seperti packaging dan delivery yang diberikan oleh perusahaan tidaklah cukup, melainkan bagaimana perusahaan tersebut meraih kepercayaan dari konsumen, sehingga konsumen tidak ragu dalam menggunakan layanan mereka dan tidak mudah beralih kepada layanan kompetitor. Kepercayaan konsumen ini sulit diperoleh dalam kurun waktu yang singkat dan memerlukan tahapan. Tahapan sebelum konsumen menjadi percaya dan loyal terhadap suatu produk umumnya dimulai dengan kategori innovators $(2.5 \%)$, early adopters $(13.5 \%)$, early majority (34\%), late majority (34\%), sampai dengan laggards (16\%). Sebagai implikasinya, dengan adanya moda baru dalam transaksi bisnis E-Commerce di dunia maya, maka secara signifikan menuntut perubahan perilaku, kebiasaan ataupun cara bertransaksi konsumen lama sehingga membentuk suatu perilaku dan kebiasaan baru yang memiliki nilai manfaat yang lebih daripada sebelumnya.

\section{EVOLUSI JEJARING SOCIAL MEDIA}

Pada tahun 2009, situs pertemanan Facebook berhasil mengangkat Mark Zuckerberg menjadi milyarder termuda di abad ini. Facebook adalah salah satu perusahaan jejaring social media tersukses di dunia yang saat ini diakui oleh banyak orang, dengan jumlah karyawan lebih dari 2.000 orang dan anggota aktif sebanyak 500 juta orang, berkantor pusat di California, Amerika Serikat. Perusahan jejaring Social media ini mendadak tumbuh berkembang dengan pesat dengan revenue mencapai USD 52 Juta pada tahun 2006 menjadi USD 2 Miliar pada tahun 2010 yang diterimanya dari hasil penjualan iklan.

Sebelum masuk ke arena komersial, kesuksesan Facebook diawali dengan jejaring sosial untuk keperluan pertemanan di lingkungan sekolah. Melalui pengembangan aplikasi teknologi web, Facebook berhasil merekayasa hubungan interaksi sosial sehingga menarik perhatian anggotanya untuk saling memberi komentar baik di wall, memposting link sebuah website, meninggalkan pesan pribadi seperti pada surat elektronik (e-mail), fasilitas online chatting, sharing foto, lagu ataupun video, dan berbagai macam aplikasi lainnya seperti memberi ucapan dan hadiah selamat ulang tahun, membuat forum diskusi, event dan aplikasi games yang sangat diminati oleh kalangan generasi muda (Gambar 4). Diharapkan dengan fitur tersebut anggota yang sudah memiliki akun Facebook tertarik mengajak teman-temannya untuk bergabung dalam komunitas jejaring social media ini, guna mendapatkan informasi terkini, menjalin kerhubungan (connectivity) dan mengembangkan komunitasnya menjadi komunitas yang lebih menyenangkan (fun). 


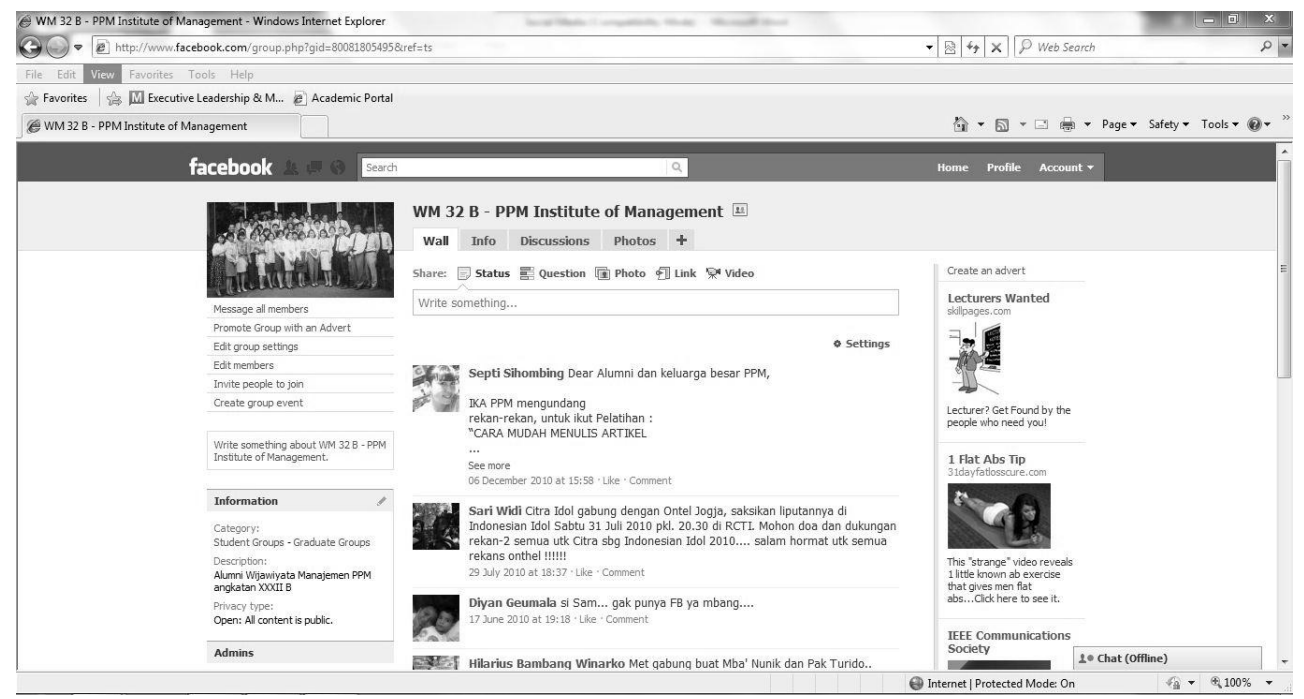

Gambar 4.

Contoh Tampilan Situs Facebook

Fasilitas yang dikembangkan oleh Facebook ternyata berkembang lebih dari sekedar komunitas jejaring pertemanan biasa dan menemukan bentuk baru menjadi komunitas jejaring penggemar (fans), seperti misalnya penggemar artis tertentu, kelompok penggemar musik dan hobi tertentu dan bahkan penggemar terhadap produk bisnis tertentu. Dari perkembangan hubungan interaksi inilah maka para pebisnis melihat peluang untuk memasarkan barang dan jasanya melalui jejaring social media dalam bentuk iklan promosi. Manfaat lain yang dapat diperoleh oleh perusahaan dengan membuat akun perusahaan (fans page) di Facebook adalah perusahaan akan lebih mengerti apa yang dibutuhkan dan diinginkan oleh pelanggan melalui rekaman percakapan (conversation) komunitas pelanggannya, baik melibatkan perusahaan, karyawan ataupun pelanggannya dengan cepat dan online 24/7.

Perusahaan dalam hal ini menikmati manfaat dalam hal penghematan biaya riset pemasaran tradisional yang biasanya harus dilaksanakan secara rutin dari waktu ke waktu. Perusahaan juga dapat membuat suatu event tertentu untuk meningkatkan loyalitas pelanggan, menampilkan informasi produk baru, melakukan jajak pendapat (polling) dengan cara yang lebih efektif dan efisien.

Dengan meningkatnya popularitas Facebook dan jejaring social media lainnya, maka bukanlah mustahil bahwa perusahaan yang memiliki kompetensi di bidang social media ke depan berpotensi untuk berevolusi menjadi perusahaan yang menghasilkan revenue yang lebih besar sebagaimana yang dihasilkan oleh perusahaan E-commerce semacam Amazon.com dan Zappos.com.

Dapat dibayangkan kemudian apabila perusahaan-perusahaan dotcom ini melakukan strategic alliance dengan perusahaanperusahaan jejaring social media, maka hal ini akan mendorong proses evolusi industri social media ke arah yang lebih komersial dan secara umum ikut mendorong bertumbuhnya transaksi bisnis online dalam industri E-commerce.

\section{PENUTUP}

Dari paparan dan analisis di atas dapat disimpulkan bahwa pertumbuhan bisnis perdagangan di dunia maya (E-commerce) tak terlepas dari peran industri jejaring social media, di mana tren jumlah anggotanya semakin berkembang secara signifikan dewasa ini dan mampu menciptakan peluang bisnis yang baru.

Sebagaimana dipercaya oleh banyak pakar multimedia bahwa dengan ditemukannya platform baru teknologi web, hubungan interaktif yang "hilang" selama ini sudah bukan lagi menjadi hambatan bertumbuhnya industri perusahaan-perusahaan E-commerce di kemudian hari. Di lain pihak perusahaan- 
perusahaan skala global ke depan pun akan mencoba untuk mengembangkan bisnisnya di dunia maya, baik dengan mengembangkan website-nya secara mandiri maupun berkolaborasi dengan perusahaan jejaring social media.

Keputusan manajemen dalam hal pengelolaan web interaktif ini sangat bergantung pada beberapa faktor seperti misalnya sejauh mana perusahaan dapat meningkatkan revenuenya serta mengurangi biaya promosi dan operasionalnya, dan sejauh mana kesiapan manajemen perusahaan merespon setiap perubahan yang terjadi dengan cepat karena konsekuensi hubungan interaktif antar perusahaan, karyawan dan pelanggan yang semakin transparan.

Ke depan tidaklah mustahil bahwa perusahaan-perusahaan jejaring social media akan berkolaborasi bahkan berevolusi dan mengembangkan bisnisnya ke arah E-commerce. Namun demikian masih ada tantangan yang harus dihadap oleh pebisnis online ini dari sudut pandang konsumen. Yakni sejauh mana industri jejaring social media secara konsisten mampu mempertahankan dan meningkatkan jumlah anggota aktifnya tanpa mengurangi tingkat kepercayaan konsumen, serta jaminan akan kerahasiaan data pribadi pelanggan dan data bisnis perusahaan yang menggunakan jasa online di media yang sama. 


\section{DAFTAR PUSTAKA}

Armstrong, Gary \& Kotler, Philip. $10^{\text {th }}$ Ed. (Global Ed.). Marketing: An Introduction. New Jersey: Pearson Education, Inc.. 2011.

Berry, Leonard L., Shostack, G.L., Upah, G.D. Relationship Marketing. Chicago: American Marketing Association. 1983.

Form 10-K, Amazon.com, Inc. 2010. United States Securities and Exchange Commission, Washington D.C. 20549.

Gide, Ergun Gide \& Shams, SM Riad. The Role of Web-based Promotion on the Development of Relationship Marketing (RM) Model to Enable Sustainable Growth. Central Queensland University, Sydney, Australia: Procedia Computer Science 3 (2011)/1060-1073. . 2011.

Lefebvre, Louis A. \& Lefebvre, Elisabeth. E-commerce and virtual enterprises: issues and challenges for transition economies. Montreal, Quebec, Canada: Pergamon. 2000.

Pakagula, Jo. Mark Zukerberg: Rahasia Mark Menjadi Miliarder di Usia 20 Tahun. Yogyakarta: Nedia Pressindo . 2009.

Rogers, Everett M. ${ }^{\text {th }}$ Ed. Diffusion of Innovations. New York : The Free Press. 2003.

Stelzner Michael A. \& Mayfield, Antony. What is a Social Media? Includes Annual Marketing Report. United Kingdom: iCrossing. 2011.

Womack, Brian. December 16, "Facebook 2010 Sales Said Likely to Reach \$2 Billion, More Than Estimated”, Bloomberg news. 2010. 